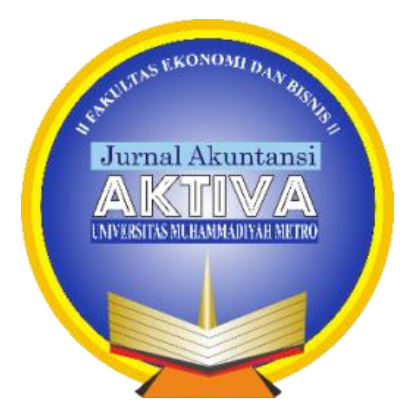

Jurnal Akuntansi AKTIVA, Vol 1, No 2, Oktober 2020

\title{
ANALISIS EFISIENSI PENGGUNAAN MODAL KERJA PADA CV. ALPAN TONDON PERKASA PERIODE 2016-2017
}

\author{
${ }^{1}$ Riza Eka Prastiwi, ${ }^{2}$ Jawoto Nusantoro, ${ }^{3}$ Ana Septiani \\ Universitas Muhammadiyah Metro, J1. Ki Hajar Dewantara, 34111, Lampung, Indonesia \\ Universitas Muhammadiyah Metro, J1. Ki Hajar Dewantara, 34111, Lampung, Indonesia \\ Universitas Muhammadiyah Metro, Jl. Ki Hajar Dewantara, 34111, Lampung, Indonesia \\ Email: rizaekaprastiwi@gmail.com, pakjawoto@yahoo.co.id, anaseptiani137@gmail.com.
}

\begin{abstract}
Prastiwi, riza, eka. 2020. Analysis of the use of capital CV alpan tondon CV. The final task. The $\mathrm{d} 3$ accounting study program, the faculty of economics and business of metro university.

An analysis that describes by calculating the ratio of existing ratios in the company using certain formulas. The results showed that the level of ratios for three years: (1) Liquidity ratios obtained Current Ratio results of $138.2 \%, 111.7 \%$, Quick Ratio of $130 \%, 102 \%$. (2) Solvency Ratio results obtained from the Debt to Equity Ratio of 10.28x, 6.27x, Debt to Total Assets Ratio of 1.18x, 1.05x. (3) The financial condition based on the calculation of good ratios and the company's performance has increased every year.
\end{abstract}

Key words: use of work capital, monetary ratio.

\begin{abstract}
ABSTRAK
Prastiwi, Riza, Eka. 2020. Analisis Penggunaan Modal Kerja CV Alpan Tondon Perkasa. Tugas Akhir. Program Studi D3 Akuntansi, Fakultas Ekonomi dan Bisnis Universitas Muhammadiyah Metro.

Analisis yang mendiskripsikan dengan cara menghitung rasio rasio yang ada diperusahaan dengan menggunakan rumus-rumus tertentu. Hasil penelitian menunjukkan bahwa tingkat rasio-rasio selama tiga tahun: (1) Rasio Likuiditas diperoleh hasil Current Ratio sebesar 138,2\%, 111,7\%, Quick Ratio sebesar 130\%, 102\%. (2) Rasio Solvabilitas diperoleh hasil Debt to Equity Ratio sebesar 10,28x, 6,27x, Debt to Total Assets Ratio sebesar 1,18x, 1,05x. (3) Kondisi keuangan berdasarkan perhitungan rasio-rasio baik dan kinerja perusahaan setiap tahun mengalami kenaikan.
\end{abstract}

Kata Kunci: use of work capital, monetary ratio. 


\section{PENDAHULUAN}

\section{Latar Belakang}

Sudah dapat dipastikan bahwa untuk menjalankan aktivitasnya setiap perusahaan membutuhkan sejumlah dana, baik dana yang berasal dari pinjaman maupun dari modal sendiri. Dana tersebut biasanya digunakan untuk keperluan investasi. Artinya, dana ini digunakan untuk membeli atau membiayai aktiva terap dan bersifat jangka panjang yang dapat digunakan secara berulang-ulang, seperti pembelian tanah, bangunan, mesin, kendaraan, dan aktiva tetap lainnya. Kedua, dana digunakan untuk membiayai modal kerja, yaitu modal yang digunakan untuk pembiayaan jangka pendek, seperti pembelian bahan baku, membayar gaji dan upah, dan biaya operasional lainnya.

Analisis terhadap laporan keuangan perusahaan sangat bermanfaat bagi penganalisa untuk mengetahui keadaan dan perkembangan keuangan perusahaan yang bersangkutan. Salah satu analisis laporan keuangan adalah rasio keuangan, analisis yang membanding-bandingkan angka dengan tujuan untuk mengevalusi kondisi keuangan dan kinerja perusahaan. Laporan sumber dan penggunaan modal kerja akan membantu manajer keuangan dalam melaksanakan kegiatan perusahaan dalam hal menentukan jumlah dana yang tersedia dan membantu manajer keuangan dalam merencanakan anggaran sebaik-baiknya untuk dapat menghindari hal-hal yang tidak diinginkan perusahaan apabila perusahaan kekurangan dana yang mengakibatkan perusahaan sulit berkembang. Kekurangan modal kerja yang terus menerus juga akan menghambat perusahaan mencapai tujuan.

Begitu juga dengan CV. Alpan Tondon Perkasa, perusahaan di Muara Enim yang bergerak pada bidang perdagangan kayu akasia dalam mengelola modal kerjanya, perusahaan dituntut supaya selau mempertahankan jumlah modal kerja yang menguntungkan agar perusahaan dapat beroperasi secara berkesinambungan, serta sikap terbukanya dengan laporan keuangan agar para pemangku kepentingan dengan mudah mengetahui bagaimana kondisi keuangan CV. ALPAN TONDON PERKASA. Oleh karena itu CV. Alpan Tondon Perkasa harus hati-hati dalam menangani masalah keuangan terutama dalam pengelolaan pengunaan modal kerja. Laporan pengunaan modal kerja ini merupakan suatu laporan yang berguna bagi pihak manajemen perusahaan, para kreditur, para pemegang saham, dan pihak lain-lainnya. Adanya modal kerja yang cukup sangat penting karena dengan modal kerja yang cukup perusahaan akan berjalan sesuai kapasitasnya yang memungkinkan perusahaan untuk beroperasi dengan seekonomis mungkin dan perusahaan tidak mengalami kendala dalam menghadapi biaya-biaya yang mungkin akan timbul di kemudian hari. Akan tetapi modal kerja yang berlebihan juga tidak baik, adanya dana yang tidak produktif akan menimbulkan kerugian bagi peruasahaan karena adanya peluang untuk memperoleh keuntungan disia-siakan. Demikian juga ketidak cukupan dalam modal kerja merupakan sebab utama kegagalan suatu usaha.

CV. ALPAN TONDON PERKASA pada umumnya sama dengan perusahaan lainnya yaitu memiliki beberapa sumber modal kerja selain dari modal pribadi, investor (pihak ketiga) dan hutang 
bank, dan CV. ALPAN TONDON PERKASA juga ingin membesarkan usahanya dengan memiliki cabang di Bangka, lahan dan kendaraan angkutan juga milik sendiri,sehingga banyak modal yang terpakai untuk aktiva tetap yang seharusnya modal usaha dipakai untuk kegiatan operasional dan membeli bahan baku guna proses penjualan agar perusahaan dapat berjalan dengan efektif. (wawancara: Etty Yuniar staff keuangan CV ALPAN TONDON PERKASA).

\section{Perumusan Masalah}

Berdasarkan latar belakang diatas maka penulis membuat perumusan masalah sebagai berikut: Bagaimana tingkat rasio likuiditas dan aktivitas di CV. ALPAN TONDON PERKASA?

\section{Tujuan Penelitian}

Berdasarkan dengan rumusan masalah yang dikemukakan oleh penulis untuk mengukur tingkat rasio likuiditas dan aktivitas pada CV ALPAN TONDON PERKASA apakah sudah efisiensi penggunaan modal kerjanya.

\section{LANDASAN TEORI}

\section{Definisi Modal Kerja}

Menurut Eugene. F Brigham and Joel. F Houston (2006: 131) menyimpulkan "modal kerja atau juga kadang disebut modal kotor adalah aktiva lancar yang digunakan dalam operasi perusahaan". Modal kerja adalah investasi sebuah perusahaan pada aktiva-aktiva jangka pendek (kas, sekuritas, persediaan dan piutang). Berdasarkan pengertian diatas kita dapat menarik sebuah kesimpulan bahwa modal kerja merupakan seluruh komponen aktiva lancar dikurangi dengan seluruh total kewajiban lancar (utang jangka pendek) atau disebut juga net working capital.

\section{Pengertian Efesiensi}

Efisiensi adalah suatu suatu tingkat ukuran keberhasilan yang dapat dinilai dari segi besarnya sumber atau biaya untuk mencapai hasil dari kegiatan yang dijalankan. Efisiensi di dalam perusahaan sangat dibutuhkan untuk tetap menjaga kelangusungan perusahaan serta mampu memberikan nilai tambah yang lebih kepada konsumen yang tidak diberikan oleh perusahaan pesaing. Menurut Kamus Besar Bahasa Indonesia (KBBI) efisiensi merupakan kemampuan menjalankan tugas dengan baik dan tapat (dengan tidak membuang waktu, tenaga, dan biaya).

\section{Rasio Likuiditas}

Rasio likuiditas adalah rasio yang menunjukan kemapuan perusahaan untuk membayar kewajiban jangka pendeknya.

\section{Rasio Lancar}

Rasio ini dihitung dengan cara Aktiva Lancar dibagi dengan Kewajiban Lancar.

$\underline{\text { Current Assets }}$

Current Liabilities 


\section{Rasio Cepat}

Rasio cepat beertujuan mengukur tingkat perusahaan dapat memenuhi kewajibannya, tanpa harus melikuidasi atau bergantung pada persedian.

Rumus perhitungan Rasio Cepat:

\section{Current Assets - Inventories \\ Current Liabilities}

\section{Rasio Aktivitas}

Rasio Akivitas yaitu seperangkat rasio untuk mengukur seberapa efektif perusahaan mengelola aktivanya, apakah jenis aktiva yang dilaporkan dalam neraca sudah wajar, terlalu tinggi atau terlalu rendah jika dibandingkan dengan penjualan.

\section{Perputaran Persediaan}

Rasio ini bertujuan untuk melihat sejauh mana tingkat perputaran persediaan yang dimiliki oleh suatu perusahaan. Adapun rumusnya sebagi berikut:

\section{Cost of Good Sold}

Average Inventory

\section{Rasio Perputaran Aktiva Tetap}

Rasio ini melihat sejauhmana aktiva tetap yang dimiliki oleh perusahaan memiliki tingkat perputarannya secara efektif, dan memberikan dampak pada keuangan perusahaan. Adapun rumusnya sebagai berikut:

$$
\frac{\text { Sales }}{\text { Fixed Asset-net }}
$$

\section{HASIL DAN PEMBAHASAN}

Hasil analisis dari data keuangan baik analisis rasio likuiditas, maupun aktivitas untuk menilai efesiensi penggunaan modal kerja CV Alpan Tondon Perkasa Kabupaten Muara Enim.

a. Posisi keuangan CV. Alpan Tondon Perkasa Kabupaten Muara Enim dilihat dari tingkat rasio likuiditas dari tahun 2016-2017 dalam posisi baik karena total aktiva lancer masih lebih besar daripada total hutang lancar. Asumsi dari rasio likuiditas adalah jika aktiva lancer lebih besar dari hutang maka keuangan perusahaan dalam kondisi baik, karena perusahaan mampu dalam membayar hutang jangka pendeknya. Hasil dari perhitungan Current Ratio tahun 2016 dan 2017 masing-masing adalah 138,2\% dan 111,7\%. Sedangkan hasil perhitungan Quick Ratio tahun 2016 dan 2017 masing-masing 130\% dan 102\%. Meskipun mengalami penurunan tingkat likuiditas CV Alpan Tondon Perkasa Kabupaten Muara Enim masih dalam kategori wajar. Faktor penyebab penurunan tingkat likuiditas adalah Hutang lancar yang timbul meningkat karena banyak hutang yang jatuh tempo pembayaran, selain itu hutang 
pada pihak ketiga pun mengalami kenaikan sampai dua kali lipat, ini karena CV Alpan Tondon Perkasa memang banyak mencari dana diluar sana atau pihak ketiga untuk menambah sumber modal CV dan juga membeli kendaraan dan lahan (aktiva tetap). Dengan demikian CV Alpan Tondon Perkasa dapat dikatakan dalam keadan likuid.

b. Dari perhitungan rasio aktivitas yang telah dilakukan maka terlihat bahwa perputaran persedian pada CV Alpan Tondon Perkasa tahun 2016 dan 2017 adalah 10,28 kali dan 6,27 kali yang artinya selama tahun 2016 dan 2017 terjadi perputaran persediaan sebanyak 10,28 kali dan 6,27 kali. Terjadi penurun perputaran persediaan pada tahun 2017 sebesar 4,01 kali. Penurunan tersebut terjadi karena persedian mengalami kenaikan sebesar 307.2225.000 hal itu disebabkan CV Alpan Tondon Perkasa membuka lahan baru untuk memuat stok persedian kayu yang lebih besar. Sedangkan hasil dari rasio aktivitas perputaran aktiva tetap tahun 2016 sebesar 1,18 kali artinya setiap Rp 1,00 aktiva tetap yang dimiliki perusahaan mampu menghasilkan penjualan Rp1.18, sedangkan pada tahun 2017 terjadi penurunan perputaran aktiva tetap menjadi 1,05 kali yang artinya setiap Rp 1,00 aktiva tetap yang dimiliki perusahaan mampu menghasilkan penjualan Rp1.05. Hal ini terjadi karena kenaikan total Aktiva tetap sebesar Rp. 1.151.812.00 atau sekitar 24\% dari tahun 2017 aktiva tetap itu meliputi pembelian lahan, pembelian kendaraan kantor, dan pembukaan lahan baru atau anak cabang. Penjualan pun mengalami tingkat kenaikan sebesar Rp 1.606.810.000. Peningkatan penjualan pada tahun 2017 terjadi karena CV Alpan Tondon Perkasa membuka lahan baru yang memiliki banyak kayu atau persediaan yang siap dijual. Dinilai dari tingkat pertumbuhan rasio perputaran aktiva tetap tahun 2016-2017 perusahaan baik mengelola aktiva yang dimilikinya. Jadi jika dinilai dari rasio akivitasnya CV Alpan Tondon Perkasa tahun 2016-2017 dalam kondisi baik.

\section{KESIMPULAN DAN SARAN}

\section{Kesimpulan}

Berdasarkan penelitian yang telah penulis lakukan terhadap laporan keuangan yang diperoleh dari CV AlpanTondon Perkasa Muara Enim periode 2016, 2017 dengan menggunakan analisis rasio likuiditas dan aktivitas dapat penulis untuk mengetahui kondisi CV Alpan Tondon Perkasa saat ini penulis dapat menyimpulkan:

1. Jika dilihat dari analisis perhitungan rasio likuiditasnya (kemampuan membayar hutang jangka pendek) dalam posisi baik, meskipun pertumbuhan rasio likuiditas mengalami penurunan ,persentase CV Alpan Tondon Perkasa sudah melebihi dari seratus persen yang artinya aktiva lancar lebih besar daripada hutang lancar.

2. Jika dilihat dari analisis perhitungan rasio aktivitas dalam kondisi baik, CV Alpan Tondon Perkasa dapat meningkatkan penjualannya dikarenakan banyak persediaan yang melimpah dari hasil membuka lahan dan membeli kayu-kayu masyarakat. 


\section{Saran}

Berdasarkan hasil analisis dan kesimpulan yang telah diambil, maka penulis menyarankan:

1. Bagi perusahaan

Likuiditas harus ditingkatkan lagi dengan cara mengurangi sumber modal dari hutang dan menekan biaya-biya yang tidak diperlukan, manfaatkan sumber modal dengan sebaikbaiknya, bila perlu untuk aktiva tetap tidak ditambahkan lagi anggaran yang keluar, karna aktiva tetap merupakan benda atau aset yang mati (tidak dapat diuangkan dengan mudah), lebih baik menambah lagi persediaannya.

2. Bagi peneliti

Untuk mencoba menganalisis rasio keuangan lainnya, supaya pembaca lainnya mendapat wawasan yang berbeda.

\section{DAFTAR PUSTAKA}

Brigham Eugene F, Joel F. Houston. (2001). Manajemen Keuangan. Edisi kedelapan. Erlangga. Djarwanto.(2004). Pokok-Pokok Analisis Laporan Keuangan. Yogyakarta: Fakultas Ekonomi UGM. FahmiIrham. (2011). Analisis Kinerja Keuangan. Bandung:ALFABETA.

Husnan Suad dan Enny Pudjiaastuti.(2004). Dasar-Dasar Manajemen Keuangan. Edisi Keempat. Yogyakarta:UPP AMP YKPN.

Jumingan.(2005). Analisis Laporan Keuangan. Bumi Aksara.

Munawir.(1979). Analisa Laporan Keuangan. Yogyakarta: Liberty.

Pratowodwi, Rika Juliaty. (2002). Analisis Laporan Keuangan Konsep dan Aplikasi. Edisi Revisi. Yogyakarta: UPP AMP YKPN.

Prawirosentono Suyadi. (1999). Manajemen Sumber Daya Manusia Kebijakan Karyawan. Yogyakarta: BPFE Fakultas Ekonomi UGM.

Suyanto, Jawoto Nusantoro. (2016). Analisis Laporan Keuangan: Aplikasi Konsep \& Metode. Metro: Fakultas Ekonomi UM Metro. 